\title{
The Effects of Government Regulation and Distinctive Capability on the Cost Leadership Strategy to Drive the Business Performance of Minimarket Chain
}

\author{
Hans Harischandra Tanuraharjo \\ Bunda Mulia University, Jakarta, Indonesia \\ Email: hans.hchandra@gmail.com
}

ARTICLE INFO

Date Received: 21

November 2020

Revision Date : 13

December 202

Date Received : 05

January 2021

\section{Keywords:}

Business

performance;

Cost leadership

strategy;

Distinctive capability;

Government

regulation

\begin{abstract}
The minimarket competition in Indonesia is very tight and dominated by the two largest minimarket chain, Indomaret and Alfamart. This study aims to examine the effects of government regulation and distinctive capability on the cost leadership strategy and its implications for the business performance of minimarket chain in Indonesia. It is based on empirical gap, not based on theoretical gap. The variables of distinctive capability and cost leadership strategy are relevant to the competitive advantage and sustainability.The method is explanatory survey, and the data is analyzed quantitatively on primary data. The unit of analysis is a minimarket chain in Indonesia. Time horizon is a cross section (one shoot). The populations are all minimarket chain companies in Indonesia which has the same set of characteristics amounted to 20. The analysis design used in this study is Partial Least Square. The coverage of samples under 100 respondents is very valid to use PLS. The results showed that cost leadership strategy dominantly was influenced by ownership of distinctive capability and was supported by government regulation. Cost leadership strategy has the most influence in directly increasing business performance. Government regulation and distinctive strategy can directly improve business performance, but the effect is smaller when compared to indirect effects through the cost leadership strategy. The findings of this study have implications for the management that efforts to improve business performance rely on the development of a cost leadership strategy, which is built on ownership of distinctive capability and adaptation of government regulation. Cost leadership strategy is suitable to be applied in this industry because of its hypercompetitive market structure. In addition, government regulations have a significant impact on the retail industry's strategy in Indonesia.
\end{abstract}

Coresponden Author:

Email: hans.hchandra@gmail.com Article with open access under license

\section{INTRODUCTION}

The Global Retail Development Index (GRDI) ranked Indonesia as the 15th developing country for retail investment purposes, where in the previous year Indonesia was ranked 19.

The Indonesian retail market is still considered attractive for foreign investors, especially global ones. This is evidenced by the continued entry of global retailers starting in 2014 such as Courts Asia (Singapore), Parkson Group (Malaysia), Central Department Store (Thailand), and IKEA (Sweden).

Many global and national retail companies are aggressively investing and expanding in various formats of modern retail businesses, such as hypermarkets, supermarkets and minimarkets. in the 2012-2014 period, the minimarket format experienced annual significant growth compared totraditional shops, supermarkets, and hypermarkets (Pearce \& Robinson, 2013). The minimarket format experienced the most rapid growth and caused various changes in the retail industry environment, which became a phenomenon in the competitive strength of the retail industry in Indonesia and impacted business performance in addition to competition between companies.

The minimarket network is experiencing pressures in the continuity of its business, such as: the emergence of various new arrivals, both local and global retailers, negative accusations from various circles that the minimarket network has killed traditional retail traders, and the increasingly has limited scope for business expansion related to regulations and problems licensing. 
The minimarket network business competition in Indonesia is very tight. Its market share of minimarket networks in Indonesia is currently dominated by the two largest minimarket network companies named Indomaret and Alfamart, in which each of them which controls a market share of over $43 \%$. The dominance of these two largest minimarket networks is often found to be closely located and even side by side, in which they are offering a variety of attractive services and promotional programs. The growth in minimarket network sales is thought to have resulted from the expansion of the opening of new outlets, but their business performance and outlets sales are believed to decline in line with the increasing level of competition around the outlets.

Along with the level of competition that has a negative effect on sales, there has been an increase in operational costs including in provincial/city/regency minimum wages (UMR, Upah Minimum Regional), electricity costs, shop/land rental fees, licensing fees, transportation costs, and etc. This situation caused the profitability of the minimarkets per-store business to decrease compared to previous years.

This fact shows the problem that the business performance of minimarket chain in Indonesia is not yet optimal. Referring to the above business competition conditions, the low performance of minimarket network business in Indonesia, allegedly caused by its lack ability to design cost leadership strategy. A superior competitive strategy is an effort creating sustainable competitive advantage through low cost strategies, speed-based strategies, and differentiation strategies (Prasad, 2011). The phenomenon shows that the products offered so far tend to not differ from the selling price of the products offered by competitors. On the other hand the products offered to customers both in terms of product quantity and product quality, do not seem to differ much from products offered by competitors.

In addition, the minimarket network management has not been able to effectively develop unique capabilities. The company's unique capabilities are developed from three types of resources: tangible resources, intangible resources and organizational capabilities [2]. In the retail business, location is the most important tangible assets. Mistakes in determining the location will have a negative impact on further business continuity.

Minimarket network companies that will continue to develop the expansion of outlets will face difficulty in buying property assets in the form of shop houses or land as it requires huge large capital to develop the minimarket network. Undeniably, it will be difficult to do an exit strategy by closing the store and then selling it when the minimarket business performance in an area begins to decline.
Minimarket chain companies develop a network of outlets with a location rental system (shop or land) and a franchise system. After surveying the location to an area and determining the exact location, the minimarket company will conduct a lease process with the landlord. The leasing process is carried out by negotiation and often scrambles to bargain with the main competitors.

Under these conditions the landlord has a bargaining position that benefits greatly by installing the highest rental fee. Such conditions often lead to unethical and dishonorable business practices, such as marking up rental fees, unilateral cancellations, etc. In the end this condition resulted in a very high cost of doing business with the surge in location rental fees. For this reason, a careful break event point and feasibility study analysis is needed before determining the right location and winning the negotiation of the location rental fee.

In addition, minimarket network companies face major issues related to government regulations. The management must inevitably have to adapt the licensing process and continue to observe and deal with government regulations. They must be prepared to adapt all formal and nonformal provisions by coordinating effectively with the local government in the licensing process associated with opening a minimarket, in which requireshigh costs and the value is never certain.

Considering this issue, this study aims at examining the effect of government regulation and distinctive capability on the cost of leadership strategy and its implications on the business performance of minimarket chains in Indonesia. This research is based on empirical gap, not based on theoretical gap. The variables of distinctive capability and cost leadership strategy are relevant to the topic of sustainability and management innovation.

\section{Literature Review \\ Government Regulation}

The strength of industrial competition includes the bargaining power of buyers and suppliers who them take care of the process of input and output through the process; the threat of new entrants, and the threat of a replacement (David, David, \& David, 2017). Five broad categories of external forces, namely: (1) economic power, (2) social, cultural, demographic, and environmental forces, (3) political, government and legal forces, (4) technological strength, and (5) competitive strength (Wheelen, Hunger, Hoffman, \& Bamford, 2017).

In relation to industry analysis, there are six forces of industrial competition: the threat of new entrants, competition among players in the industry, the bargaining power of buyers, the threat of product or service substitution, and the bargaining power of suppliers. The sixth power named the 
relative strength of other stakeholders includes various stakeholder groups from the task environment, such as the government (if not explicitly included in a group), the local community, creditors (if not included in the supplier), trade associations, certain interest groups, associations (if not included in suppliers), shareholders, and supplementary powers (Levy, 1982).

\section{Distinctive Capability}

To measure the resources owned by a company as sources of strength or weakness is done by comparing the resources they have today with the resources they have before; or by comparing resources owned by major competitors and the industry in general. Resource competency as the main source of uniqueness of a company can be created through physical assets (land, equipment, and location); human resource assets (number of employees and expertise), and organizational assets (culture and reputation) (Levy, 1982). In relation, a core competency is a capability that a firm emphasizes and excels in doing while in pursuit of its overall mission. Core competencies that differ from those found in competing firms would be considered distinctive competencies [2].

In developing sustainable competitive advantage, retail companies must have seven resources (sources of advantage): human resources management, distribution and information systems, location, customer loyalty, unique and information systems, vendor relations, customer service, and unique merchandise (Berman, 2010).

In accordance with the minimarket chain analysis unit, the distinctive capability variable in this study was measured by physical assets, intangible assets, and organizational capabilities.

\section{Cost Leadership Strategy}

Competitive strategy is required as an effort to create sustainable competitive advantage using product uniqueness and cost leadership (Prasad, 2011). Related to the retail industry, business lessons from various world-class retail companies in the United States, has further developed Porter's Competitive Strategy theory: Differentiation-Based Strategy, Cost-Based Strategy (DifferentiationBased Strategy), and Value-Based Strategy. CostBased Strategy (Cost-Based Strategy) consists of: Bargaining-Based Strategy, increasing efficiency, and trade-offs between lower costs to potentially declining sales and customer satisfaction (Best, 2009).

Based on the above concept, the variable cost leadership strategy in this study was measured by bargaining power-based strategy, efficiency, and trade off dimensions

\section{Business Performance}

Business performance can be measure from the aspects of profitability, sales, and market share (Levy, 1982). Business performance is the output or the result of the implementation of all activities related to business activities, and also the indicator of business performance is sales growth and profitability (Tuma, J. M., \& Pratt, J. M. (1982). Clinical child psychology practice and training: $A$ survey. Vdots of Clinical Child \& Adolescent Psychology, 137(August 2012) et al., 2002). Business performance indicators is seen from the marketing aspect and through the company's financial performance. Measurement of business performance through marketing performance done by analyzing sales, market growth, and market share. Financial performance perspectives are measured using: (1) return on investment (ROI), (2) revenue mix, (3) asset utilization (measured by asset turnover), and (4) significant cost reduction (Alasadi \& Al Sabbagh, 2015). In addition, sales also used to measure business performance (Krapez, Skerlavaj, \& Groznik, 2012).

Referring to the concept of business performance above, the variable performance of minimarket network business in Indonesia was measured by sales volume, profitability, and market share dimensions.

\section{Hypothesis Testing}

Based on the background situation in Slovenia, it was concluded that to achieve long-term success must be based or focus also on several factors such as: corporate culture, values, and reward systems, state legislation, taxation systems, bureaucratic buffering, opportunities funding (partnership with banks, bank guarantees, venture capital, etc.). The strength of industrial competition shapes organizational resources and competitive strategies (Narula \& Upadhyay, 2010). Meanwhile, competitive forces affect industries and companies and illustrate how domestic companies must reorient strategies to overcome environmental turbulence created by regulations, market forces and competitive forces (Saaty \& Qureshi, 2011). Companies in the retail sector in Saudi Arabia could improve their performance by emphasizing excellent human resource practices (Kurt \& Zehir, 2016).

The relationship between cost leadership strategy, total quality management applications and firms' financial performance with literature review and empirical analysis. There were 449 questionnaires administered to the managers of 142 big firms (Opara, 2019). Besides, application of cost leadership strategy led to reduced costs of operation, increased production outputs and profitability (Tuma, J. M., \& Pratt, J. M. (1982). Clinical child psychology practice and training: A survey. Vdots of Clinical Child \& Adolescent Psychology, 137(August 2012) et al., 2002).

Based on the results of previous studies, the conceptual model of research is arranged as follows: 
Figure 1

\section{Conceptual Model}

The following hypotheses are arranged based on the above conceptual model:

H1: Government regulation influences the cost leadership strategy

$\mathrm{H} 2$ : Distinctive capability influences the cost leadership strategy

H3 : Government regulation influences the business performance

H4 : Distinctive capability influences the business performance

H5 : Cost leadership strategy influences the business performance

\section{METHOD}

The study employs explanatory survey, in which its objective is to test the truth of a hypothesis that has been conducted through data collection in the field. The data is analyzed quantitatively because it is based on primary data It used minimarket network in Indonesia as the unit of the analysis. Specifically, this network had a business brand consisting specific segmentation, positioning and targeting in its own market. This was done by distributing centralized management outlets in various regions in Indonesia with headquarters and branch offices in various cities/provinces/countries in Indonesia as the representative of the central office. The time horizon in this study is a crosssection/shot. Transverse pieces/one taking in which a sample of respondents is drawn from the target population and information is obtained from this sample once (Nunnally, 1994).

The population of this study is a combination of all elements of 20 minimarket network company in Indonesia having the same set of characteristics. The coverage of samples under 100 respondents is very valid to use PLS, so that the analysis design used in this study is Partial Least Square to facilitate the relationship between latent variables.

\section{RESULT AND DISCUSSION}

\section{A. Analysis of Measurement Model (Outer Model)}

Validity and reliability tests were employed to measure the latent variables and the indicators in measuring the dimension that is constructed. Cronbachs Alpha's value was used to measure the reliability of dimension in measuring variables. The value of Cronbachs Alpha bigger than 0.70 indicates that the dimensions and indicators is reliable in measuring variables. Composite reliability and Cronbachs Alpha $>0.70$, show that all of variables in the model estimated fulfill the criteria of discriminant validity (Chin, 1998). Table 2 presents the result of outer model for each dimension on indicators.

Table 1

Measurement Model (Outer Model)

\begin{tabular}{|c|c|c|c|c|}
\hline $\begin{array}{c}\text { Variable- } \\
\text { Dimension }\end{array}$ & $\begin{array}{l}\text { Indicator- } \\
\text { Dimension }\end{array}$ & $\lambda$ & SE $(\lambda)$ & t-value \\
\hline \multirow[t]{3}{*}{$\begin{array}{l}\text { Business } \\
\text { Performance }\end{array}$} & $\begin{array}{l}\text { BP1<- } \\
\text { Business } \\
\text { Performance }\end{array}$ & 0.946 & 0.010 & 92.753 \\
\hline & $\begin{array}{l}\text { BP2 <- } \\
\text { Business } \\
\text { Performance }\end{array}$ & 0,893 & 0.024 & 37.054 \\
\hline & $\begin{array}{l}\text { BP3 <- } \\
\text { Business } \\
\text { Performance }\end{array}$ & 0.686 & 0.056 & 12.344 \\
\hline \multirow[t]{3}{*}{$\begin{array}{l}\text { Cost } \\
\text { Leadership } \\
\text { Strategy } \\
\end{array}$} & $\begin{array}{l}\text { CLS1 <- Cost } \\
\text { Leadership } \\
\text { Strategy }\end{array}$ & 0.718 & 0.065 & 11.007 \\
\hline & $\begin{array}{l}\text { CLS2 <- Cost } \\
\text { Leadership } \\
\text { Strategy }\end{array}$ & 0.793 & 0.035 & 22.548 \\
\hline & $\begin{array}{l}\text { CLS3 <- Cost } \\
\text { Leadership } \\
\text { Strategy }\end{array}$ & 0.777 & 0.050 & 15.648 \\
\hline \multirow[t]{9}{*}{$\begin{array}{l}\text { Distinctive } \\
\text { Capability }\end{array}$} & $\begin{array}{l}\text { DC1<- } \\
\text { Tangible } \\
\text { Asset }\end{array}$ & 0.615 & 0.329 & 1.867 \\
\hline & $\begin{array}{l}\text { DC2 <- } \\
\text { Tangible } \\
\text { Asset }\end{array}$ & 0.785 & 0.079 & 9.921 \\
\hline & $\begin{array}{l}\text { DC3 <- } \\
\text { Tangible } \\
\text { Asset }\end{array}$ & 0.650 & 0.320 & 2.032 \\
\hline & $\begin{array}{l}\text { DC4 <- } \\
\text { Intangible } \\
\text { Asset }\end{array}$ & 0.826 & 0.046 & 17.820 \\
\hline & $\begin{array}{l}\text { DC5 <- } \\
\text { Intangible } \\
\text { Asset }\end{array}$ & 0.518 & 0.261 & 1.985 \\
\hline & $\begin{array}{l}\text { DC6 <- } \\
\text { Intangible } \\
\text { Asset }\end{array}$ & 0.588 & 0.118 & 5.000 \\
\hline & $\begin{array}{l}\text { DC7 <- } \\
\text { Capability Org }\end{array}$ & 0.593 & 0.276 & 2.151 \\
\hline & $\begin{array}{l}\text { DC8 <- } \\
\text { Capability Org }\end{array}$ & 0.739 & 0.078 & 9.427 \\
\hline & $\begin{array}{l}\text { DC9 <- } \\
\text { Capability Org }\end{array}$ & 0.741 & 0.092 & 8.100 \\
\hline \multirow[t]{3}{*}{$\begin{array}{l}\text { Government } \\
\text { Regulation }\end{array}$} & $\begin{array}{l}\text { Reg1<- } \\
\text { government } \\
\text { regulation }\end{array}$ & 0.767 & 0.086 & 8.881 \\
\hline & $\begin{array}{l}\text { Reg2 <- } \\
\text { government } \\
\text { regulation }\end{array}$ & 0.747 & 0.055 & 13.663 \\
\hline & $\begin{array}{l}\text { Reg3 <- } \\
\text { government } \\
\text { regulation }\end{array}$ & 0.648 & 0.071 & 9.099 \\
\hline
\end{tabular}

Cronbachs Alpha $>0.7$ and Composite Reliability $>0.7$ showed that variables have reliable indicators and variables have good reliability. 
Loading factor ( $\square \square$ obtained should be able to explain the relationship between latent variablesand indicators. The outer model showed that the indicators are valid which $t$-value $>2.10$ ( $t$ table at $\alpha$ $=0.05$ ). The result of measurement model of latent variables on their indicators shows validity in measuring latent variables

\section{B. Structural Model (Inner Model) Analysis}

The results of information collection are used in the design of the interior model of the dental clinic as an alternative to child anxiety management.

Table 2

Test of Outer and Inner Mode

\begin{tabular}{lllll}
\hline \multicolumn{1}{c}{ Variable } & $\begin{array}{c}\text { Cronbach } \\
\text { S } \\
\text { Alpha }\end{array}$ & $\begin{array}{c}\text { Composit } \\
\text { Reliability }\end{array}$ & $\begin{array}{c}\boldsymbol{R} \\
\text { Squar } \\
\boldsymbol{e}\end{array}$ & $\begin{array}{c}\mathbf{Q} \\
\text { square }\end{array}$ \\
\hline $\begin{array}{l}\text { Business } \\
\text { Performance }\end{array}$ & 0.804 & 0.884 & 0.684 & 0.449 \\
\hline $\begin{array}{l}\text { Cost } \\
\text { Leadership }\end{array}$ & 0.751 & 0.807 & 0.612 & 0.322 \\
Strategy & & & & \\
\hline $\begin{array}{l}\text { Government } \\
\text { Regulation }\end{array}$ & 0.747 & 0.765 & & 0.521 \\
\hline $\begin{array}{l}\text { Distinctive } \\
\text { Capability }\end{array}$ & 0.739 & 0.806 & & 0.365 \\
\hline
\end{tabular}

$R$ square value of Business performance and cost leadership strategy was the strong criteria (> $0.33=$ moderate), and $Q$ square values were in the large criteria, so it can be concluded that the research model was supported by the empirical condition, or in other words, the model was fit.

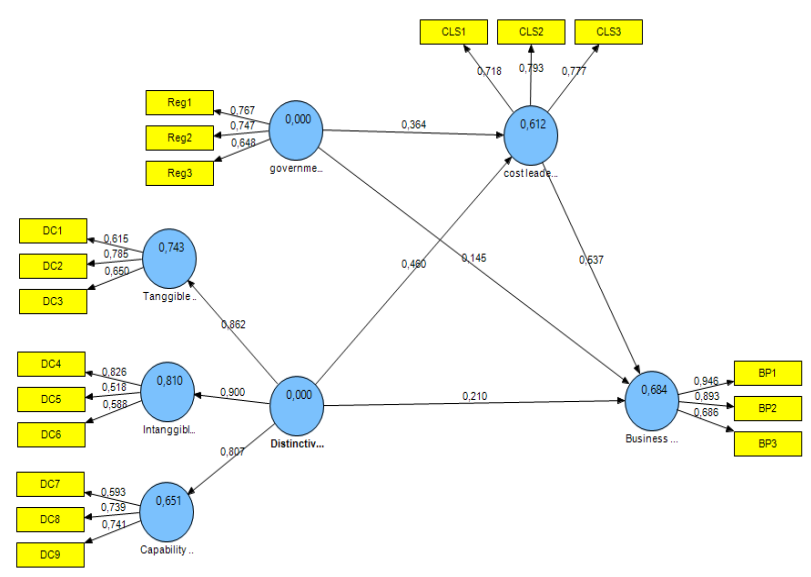

Figure 2. Complete Path Diagram of Research Model

Based on the research framework, then obtained a structural model:

$Y=0.364 X 1+0.460 X 2+\zeta 1$

$Z=0.145 X 1+0.210 X 2+0.537 Y+\zeta 2$

$\mathrm{X} 1=$ Government regulation

$\mathrm{X} 2$ = Distinctive Capability

$\mathrm{Y}=$ Cost Leadership Strategy

$Z=$ Business Performance

$\zeta_{1}=$ Residual

C. Hypothesis Testing
Below is the result of hypothesis testing both simultaneous and partially.

Table 3

Hypothesis Testing

\begin{tabular}{|c|c|c|c|c|c|}
\hline No & Hypotheses & $\gamma$ & $\mathbf{S E}(\gamma)$ & t value & $\overline{\mathbf{R}^{2}}$ \\
\hline 1 & $\begin{array}{l}\text { Government } \\
\text { Regulation -> Cost } \\
\text { Leadership } \\
\text { Strategy } \\
\end{array}$ & $0.364 *$ & 0.135 & 2.689 & 0.267 \\
\hline 2 & $\begin{array}{l}\text { Distinctive } \\
\text { Capability -> Cost } \\
\text { Leadership } \\
\text { Strategy } \\
\end{array}$ & $0.460^{*}$ & 0.147 & 3.128 & 0.346 \\
\hline 3 & $\begin{array}{l}\text { Government } \\
\text { Regulation -> } \\
\text { Business } \\
\text { Performance } \\
\end{array}$ & 0.145 & 0.109 & 1.325 & 0.045 \\
\hline 4 & $\begin{array}{l}\text { Distinctive } \\
\text { Capability -> } \\
\text { Business } \\
\text { Performance } \\
\end{array}$ & $0.210^{*}$ & 0.076 & 2.772 & 0.068 \\
\hline 5 & $\begin{array}{l}\text { Cost Leadership } \\
\text { Strategy -> } \\
\text { Business } \\
\text { Performance } \\
\end{array}$ & $0.537 *$ & 0.075 & 7.149 & 0.288 \\
\hline
\end{tabular}

Table 3 presents that partially, government regulation, and distinctive capability have influential significantly to cost leadership strategy and business performance. Distinctive capability had a greater influence on cost leadership strategy $(\mathrm{R} 2=34.6 \%)$. Then, the government regulation had no significantly direct influential to Business performance ( $\mathrm{t}$ value $<2.10$ ).

Government regulation and distinctive capability had significantly indirect effect to business performance through cost leadership strategy, thus distinctive capability have dominant effect (R2 $=24.7 \%$ ).

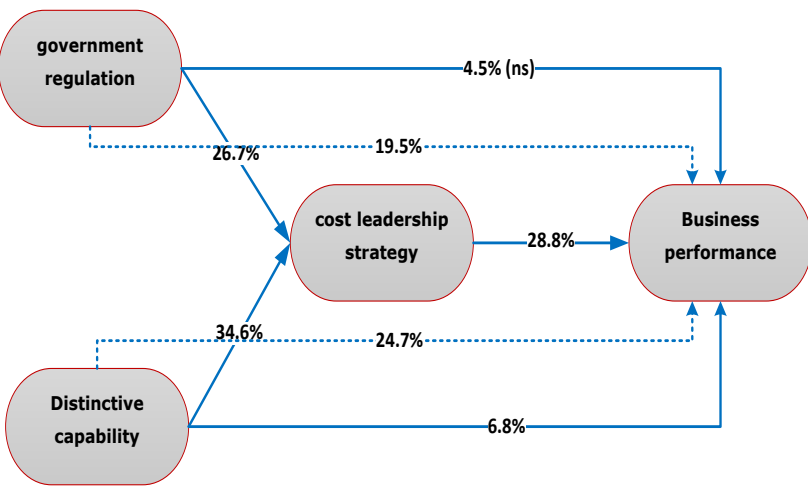

Figure 3

\section{Research Findings}

The results showed that the right strategy of cost leadership was dominantly influenced by ownership of distinctive capability (34.6\%) and was supported by the extent to which minimarket network companies were able to adapt aspects of government regulation (26.7\%). Furthermore, the cost leadership strategy could improve business 
performance by $28.8 \%$. Government regulation and distinctive strategy were also able to directly improve business performance, but the effect was smaller when compared to indirect effects through the cost leadership strategy. Distinctive capability could improve business performance by $24.7 \%$ if through a cost leadership strategy, but if it directly affects only $6.8 \%$. Government regulation was able to directly influence business performance by $4.5 \%$, but if it was through a cost leadership strategy, then the effect would be greater at $19.5 \%$.

These findings indicated that the business performance improvement of minimarket network companies was based on the development of leadership strategy cost, in which the cost leadership strategy was built on ownership of distinctive capability and adaptation of government regulation.

These findings support the results of study that shows cost leadership strategy and total quality relationship [14]. Besides, this findingis in line the finding of the research which revealed that the application of the cost leadership strategy led to reduced operations cost, increased production outputs and profitability [15].

This finding is also in line with the results of research that the strength of industrial competition shapes organizational resources and competitive strategies [11]. This finding is in accordance with the reseaarch which found that competitive forces affected industries and companies and illustrated how domestic companies must reorient strategies to overcome environmental turbulence created by regulations, market forces and competitive forces [12]. The results of this study are also in accordance with the results of the study which found that companies in the retail sector in Saudi Arabia could improve their performance by emphasizing excellent human resource practices [13].

\section{CONCLUSION}

The findings indicate the hypothesis support that government regulation influenced the cost leadership strategy, distinctive capability influences the cost leadership strategy, government regulation influences business performance, distinctive capability influences business performance, and cost leadership strategy influenced business performance.

It can be inferred that the dominant cost leadership strategy was influenced by ownership of distinctive capability and was supported by the extent to which minimarket network companies were able to adapt aspects of government regulation. Cost leadership strategy had the most influence in directly increasing business performance. Government regulation and distinctive strategy were also able to directly improve business performance, but the effect was smaller when compared to indirect effects through the cost leadership strategy.
This study has implications for minimarket chain company management efforts to improve business performance rest on the development of a cost leadership strategy, which is built on ownership of distinctive capability and adaptation of government regulation. Cost leadership strategy is suitable to be applied in this industry because of its hypercompetitive market structure. In addition, government regulations have a significant impact on the retail industry's strategy in Indonesia.

\section{REFERENSI}

Alasadi, Rami, \& Al Sabbagh, Hicham. (2015). The role of training in small business performance. International Journal of Information, Business and Management, 7(1), 293.

Berman, Barry R. (2010). Competing in Tough Times: Business Lessons from LL Bean, Trader Joe's, Costco, and Other World-Class Retailers (Paperback). FT Press.

Best, R. (2009). Market Base Management; Strategy for Growing Consumer Value and Profitability. Pearson Education. Inc, New Jersey.

Chin, Wynne W. (1998). The partial least squares approach to structural equation modeling. Modern Methods for Business Research, 295(2), 295-336.

David, Meredith E., David, Fred R., \& David, Forest R. (2017). The quantitative strategic planning matrix: a new marketing tool. Journal of Strategic Marketing, 25(4), 342-352.

Krapez, Jana, Skerlavaj, Miha, \& Groznik, Ales. (2012). Contextual variables of open innovation paradigm in the business environment of Slovenian companies. Economic and Business Review for Central and South-Eastern Europe, 14(1), 17.

Kurt, Ali, \& Zehir, Cemal. (2016). The relationship between cost leadership strategy, total quality management applications and financial performance.

Levy, F. L. (1982). Calculating the thermal conductivity of meat and fish in the freezing range. International Journal of Refrigeration, 5(3), 149-154.

Narula, Sapna A., \& Upadhyay, K. M. (2010). Strategy in turbulent environment: A case study of Indian domestic company. American Journal of Economics and Business Administration, 2(2), 160. 
Nunnally, Jum C. (1994). Psychometric theory 3E. Tata McGraw-hill education.

Opara, Chika Glory. (2019). Deviations in popular Nigerian English syntax. International Journal of Development and Management Review, 14(1), 193-207.

Pearce, John A., \& Robinson, Richard Braden. (2013). Strategic management: Planning for domestic \& global competition. McGrawHill//rwin.

Prasad, Ajit. (2011). The impact of non-market forces on competitive positioning: understanding global industry attractiveness through the eyes of ME Porter. Journal of Management Research, 11(3), 131.

Saaty, Abdalelah S., \& Qureshi, Mohammed Owais. (2011). An empirical analysis of the human resource management activities in retail sector: A study of Saudi Arabian companies. Interdisciplinary Journal of Research in Business ISSN, 2046, 7141.
Tuma, J. M., \& Pratt, J. M. (1982). Clinical child psychology practice and training: A survey. Vdots of Clinical Child \& Adolescent Psychology, 137(August 2012), 37-41. http://doi.org/10.1037/a0022390, Gobry, F. (1999). $\{$ T $\}$ his is a title. $\{$ M $\}$ y Journal, 1,120 130., Keshav, S. (2007). How to Read a Paper. Work, 37(3), 83-84. http://doi.org/10.1145/1273445.1273458, et al. (2002). Middlesex University Doctor of Professional Studies. Studies in Higher Education.

Wheelen, Thomas L., Hunger, J. David, Hoffman, Alan N., \& Bamford, Charles E. (2017). Strategic management and business policy. pearson Boston, MA. 